\title{
EMPLOYMENT RATE AND MARKET SECTOR OCCUPATION OF GRADUATES IN TRANSLATION AND INTERPRETING AT THE UNIVERSITAT AUTÒNOMA DE BARCELONA
}

\section{A INSERÇÃO LABORAL DOS TITULADOS EM TRADUÇÃO E INTERPRETAÇÃO NA UNIVERSITAT AUTÒNOMA DE BARCELONA}

Anabel Galán-Mañas*

\begin{abstract}
This article presents the results of a market study into graduate employment for graduates in Translation and Interpreting from the Universitat Autònoma de Barcelona (UAB), Spain. Based on students who have graduated in the last 10 years, the study analyses the trajectory of their academic studies, employment status and identifies factors which influence having a career related to their university studies as well as income level. The results show that there is a high level of employment among these graduates with an average income level. They also illustrate that many of the subjects participating opted to continue their university studies after their B.A. in Translation and Interpreting. Positive influencing factors on earnings levels are overeducation and having participated in study abroad programmes. The kind of work graduates do is quite diverse and to some degree is closer to transversality common to applied language studies and international relations, than the specifics of translation and interpreting.
\end{abstract}

Keywords: Labour market insertion. Graduates in Translation and Interpreting. Market study. Professional tasks. Language services.

\section{Introduction}

This article presents the results of a market study on the entry into the job market of Translation and Interpreting graduates from the Universitat Autònoma de Barcelona (UAB), Spain. The aim of this study was to gather data from two perspectives: Translation and Interpreting graduates, and employers. In regards to employers, it examines the characteristics of the posts graduates are expected to fill, the competences required and their degree of satisfaction with the training received by undergraduate students. Concerning graduates, it

*Doutora em Tradução e Estudos Interculturais. Professora de tradução do Departamento de Tradução, Interpretação e Estudos de Ásia Oriental. Universitat Autònoma de Barcelona. Email: isabel.galan@uab.cat 
analyzes their academic studies trajectory, employment status and identifies factors which influence having a career related to their university studies as well as income level. Due to limitations of space, however, this article only presents the latter perspective.

Since employment is one of society's major concerns and one of the European Union's objectives, studies on entering the job market are necessary to provide information about the ratio of people who find jobs and their working conditions. Higher education institutions also use such studies as a gauge to measure their own performance. In fact, one of the objectives of the Bologna process is to guarantee the employability of university graduates in any EU country - employability understood as being able to find a job, keep it or be mobile within the job market. Meeting this objective, as Rodríguez Céspedes (2017) states, entails coupling the education system to the guarantee of employment, which is a particularly difficult goal in the wake of a global recession which began back in 2008 (European Commission/EACEA/ Eurydice 2010, 2012; EHEA 2015).

The practice of using job market insertion indices as synonyms for university performance, however, has come under criticism. For example, Moreau and Leathwood (2006) claim that the discussion on the insertion of university students into the job market has shifted the pressure away from finding a job to training people, which has in turn diverted attention from certain structural market factors such as higher university fees, the economic crisis, gender and race discrimination in the job market, or university ranking, etc. Lee et al. (2016) are of the opinion that these studies only serve to help future candidates gain further information about different university degrees. The fact is, however, that the outcome of publishing these kinds of studies can end up compromising many degree programmes.

Despite the limitations of studies on job prospects, they are a legal requirement in Spain: the Real Decreto (Royal Decree) 1393/2007 requires Spanish universities to describe the labour market insertion of their graduates, as well as their satisfaction with the training they have received. To this end, the majority of Spanish universities nowadays have employment observatories responsible for studying graduate employment. In Catalonia this is the Agència per a la Qualitat del Sistema Universitari de Catalunya (AQU) 1, which carries out studies jointly with all the Catalan universities. The indicators gleaned from these are incorporated into the yearly process of monitoring undergraduate and M.A. programmes in order to improve quality. 
Most studies of this kind agree on asking about aspects related to employment (employed/unemployed, time spent finding the first job, entry paths into job market and which sectors), job quality (related to studies / training, salary, job satisfaction, etc.) and satisfaction with their studies (how useful in the work place, whether they would do their degree again). However, the drawback of these studies is that they measure variables generically, without engaging in any prior discussion with the universities, so what is lacking is other and more specific types of information in accordance with the degree studied.

Regarding the labour market insertion of translation and interpreting graduates in Spain, there is a study by ANECA (2004) which draws together the results of three surveys: one by the AQU, another by the Faculty of Translation and Interpreting at the UAB, and the third by the Universidad Pontificia Comillas de Madrid. From another angle, there are partial studies which focus on specific professional sectors: technical translation (Jiménez, 2002), legal translation and sworn translation (Monzó, 2002), inverse translation (Roiss, 2001), professional translation services in the Spanish market (Orth, 2005), translation for publishing houses (Ministerio de Cultura, 2010) and the work content of jobs in translation companies in Barcelona (Kuznik, 2010). Kelly (2005) attributes this dearth of studies on the translation and interpreting market to the absence of an influential professional association of translators and interpreters, while Kuznik (2014) points to a lack of concern by organisations with these professions as well as the inherent major difficulties in measuring job market insertion in the services sector due to its highly heterogeneous nature.

So, I believe it is necessary to conduct more specific market studies designed to obtain information exclusively about graduates in Translation and Interpreting, but in particular, about the specific professional tasks they have to perform, the most common language combinations in demand and the text genres they work with. This information would allow for assessing the relevance of the Translation and Interpreting degree programmes in terms of real market demands.

\section{Methodology}

The study presented here deals with the employment status of graduates in Translation and Interpreting from the Universitat Autònoma de Barcelona (UAB) between 2004-2014 and is a quantitative study which employs a descriptive methodology. The instrument used to 
gather data was an ad hoc electronic questionnaire mainly consisting of closed questions grouped as follows: sociodemographic information, academic information, job status, type of professional work and competences (see Appendix I).

The survey was conducted according to the following steps: 1) designing the questionnaire, 2) performing a pilot survey with five graduates to assess the wording and relevance of the questions, 3) revising and rewording the questions based on step 2,4) telephoning the sample group to ask for their anonymous and voluntary participation, 5) sending an email link to the electronic questionnaire to those who had agreed to participate in this study.

The sampling frame comprised 1,943 students who had graduated from the UAB School of Translation and Interpreting (FTI) between 2004/2005 and 2013/2014. A representative sample of 369 people was chosen and $\mathrm{p}=\mathrm{q}=0.5$, with a $5.51 \%$ error margin and a 95\% statistical confidence level. It was a proportional assignation sample according to year of graduation. The initial sample was drawn from probability based random sampling. The replacement was performed by means of mass mailing until it fulfilled proportional allocation for each sample once no more responses were obtained from the originally selected sample. Replacement rate was $36.10 \%$.

Table 1. Population and sample

\begin{tabular}{|c|c|c|}
\hline $\begin{array}{c}\text { Year of } \\
\text { graduation }\end{array}$ & Population & Sample (sample actually obtained) \\
\hline $2004-2007$ & 599 & $84(=84)$ \\
\hline $2007-2010$ & 533 & $75(=75)$ \\
\hline $2010-2013$ & 620 & $87(>85)$ \\
\hline $2013-2014$ & 191 & $27(>26)$ \\
\hline TOTAL & 1,943 & $272(272)$ \\
\hline
\end{tabular}

Source: Prepared by the author.

The data from the subjects was extracted from the online questionnaire and university transcripts. In order to cross-reference the survey data with academic records, a required ID number field was included, once the data was extracted from the questionnaire, the corresponding academic record information was imported using the common ID number field to link the data. After this, the ID number field was deleted from the database to preserve anonymity. 
Data analysis was performed mainly using descriptive statistics and, in some cases, bivariate statistics based on contingency tables and multiple-choice tables. The variables were measured independently and, occasionally, in combination. Some of the data has been broken down into four groups according to the time elapsed since the students graduated: less than a year ago, 1-3 years, 3-6 years and 6-9 years.

\section{Results}

\subsection{Academic trajectory}

\section{Other bachelors or M.A. degrees}

The first analysis factor is academic trajectory, that is, what other degrees alumni have pursued in addition to their B.A. in Translation and Interpreting. 14.7\% studied another bachelors', mainly Philology (4\%), followed by Journalism and Communication (2.9\%) and Tourism (1.8\%). In $63.2 \%$ of those surveyed took an M.A. or graduate studies. In $38.2 \%$ of the cases these were M.A. degrees specializing in one of the areas of translation or interpreting. 9.9\% obtained the official teaching diploma required to work in secondary schools and $4.8 \%$ in international relations. Of those who took an M.A. in one of the translations and interpreting specialization fields (see figure 1), 23.8\% were in text proofing / revision and language advisory services, $21 \%$ in audiovisual translation and $20 \%$ in translation technologies.

Figure 1. M.A. or graduate studies

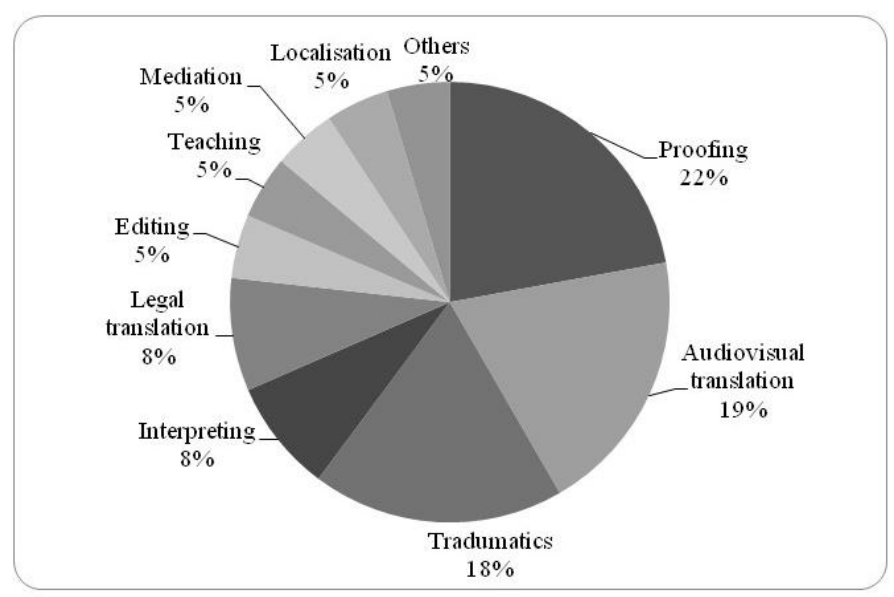

Source: Prepared by the author. 
These data appear to support Barone and Ortiz's theory (2011) that graduates from any of the Arts disciplines tend towards overeducation.

\section{Exchange students}

$33 \%$ of graduates have studied abroad through exchange programmes, the average stay being 8.7 months. The most common case was a single exchange (87.3\%), although $44.5 \%$ have participated in two and $18 \%$ in three or more. The main destination was Europe, 91\% distributed between the United Kingdom (29\%), Germany (14.6\%) and France (12.4\%) - , followed by the US (13.5\%) and Asia (11.9\%). A total of 20 different countries figure in these statistics.

\subsection{Employment status}

\section{Actively employed graduates}

The results show an overall employment level of $85.5 \%$, which is actually a progressive situation from the moment they graduate: $65.4 \%$ are working within the first year, rising to $94 \%$ three years after graduating.

Table 2. Percentage of students actively employed after graduating

\begin{tabular}{|c|c|c|c|}
\hline$<\mathbf{1}$ year & $\mathbf{1}-\mathbf{3}$ years & $\mathbf{3 - 6}$ years & 6-9 years \\
\hline $65.4 \%$ & $88.2 \%$ & $94.7 \%$ & $94 \%$ \\
\hline
\end{tabular}

Source: Prepared by the author.

Further information about those not actively employed would be valuable to determine whether this is because they have been unable to find a job, or whether a deliberate choice at this point not to enter the job market because they are undergoing further training or spending time abroad to improve their foreign language skills.

\section{Income levels}

Analysis of earnings reveals that they increase with time. Most incomes are below $€ 9,000 €$ per year during the first year after graduating and the majority of those at the other end of the time scale earn more than $€ 18,000$. $25 \%$ of graduates have gross earnings of 
between $€ 12,000$ and $€ 18,000$ a year, $5 \%$ between $€ 18,000$ and $€ 30,000$ and $10 \%$ more than $€ 30,000$.

Table 3. Income level since graduating

\begin{tabular}{|c|c|c|c|c|}
\hline & < 1 year & 1 - 3 years & 3-6 years & 6-9 years \\
\hline $\begin{array}{l}\text { Earnings mode } \\
1=<€ 9,000 \\
2=€ 9,000-€ 12,000 \\
3=€ 12,000-€ 18,000 \\
4=>€ 18,000\end{array}$ & $\begin{array}{l}\text { Mode }=1 \\
\text { Average }=2\end{array}$ & $\begin{array}{l}\text { Mode }=3 \\
\text { Average }=2.58\end{array}$ & $\begin{array}{l}\text { Mode }=4 \\
\text { Average }=3.54\end{array}$ & $\begin{array}{l}\text { Mode }=4 \\
\text { Average }=3.80\end{array}$ \\
\hline
\end{tabular}

Source: Prepared by the author.

\section{Mode of employment}

Responses to the question about the three main jobs since they finished their studies, returned 300 job experiences (each person surveyed was allowed to give more than one response). $74 \%$ work for someone else, at least part of the time, and 36.8\% are (or have been) self-employed, either full time or combined with working for someone else ${ }^{2}$. In some cases, being self-employed is sporadic since close to $10 \%$ have worked for themselves more than once. As regards their present employment - or last in the case of being currently unemployed - the following employment modes can be seen.

Actively employed graduates mainly work for third parties. However, the percentage who are self-employed (freelance or their own company) or combine working in a company with working for themselves, rises the longer they have graduated, as illustrated in figure 2.

Figure 2. Mode of employment (current or last job)

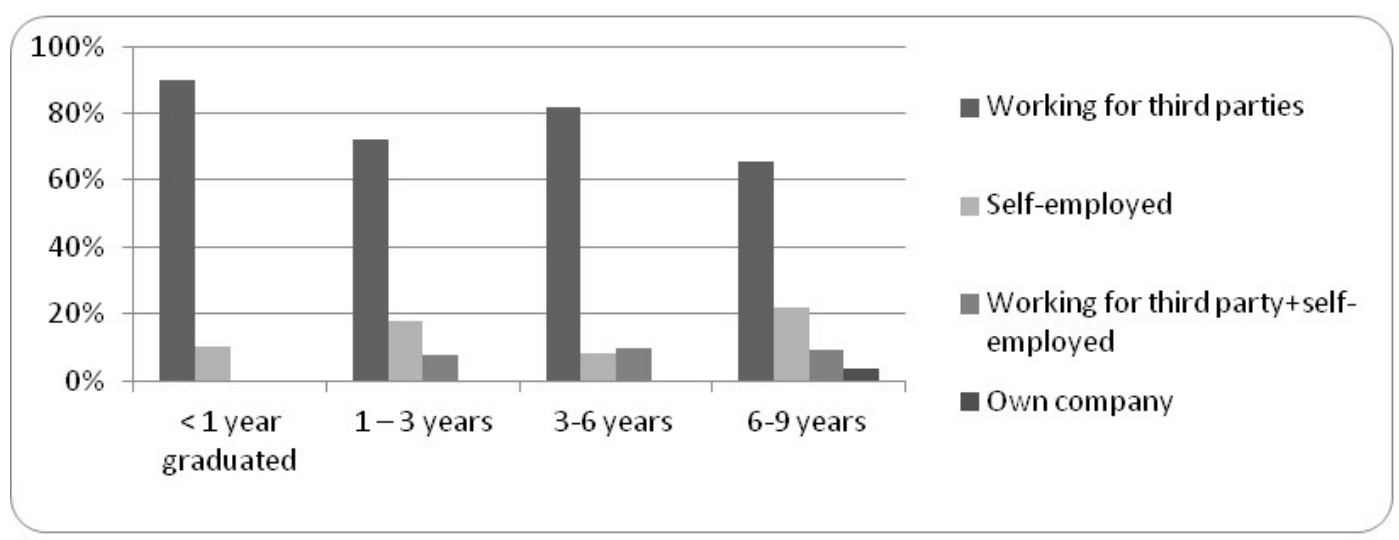

Source: Prepared by the author. 
The percentage of graduates working for themselves is quite low if we consider that $80 \%$ of the translation jobs are externalised (Kuznik, 2010).

\section{Type of contract}

Of those who work for third parties, $56 \%$ have a full-time contract while $40 \%$ have part-time contract. The majority of work contracts in the first year after graduating are parttime $(52.9 \%)$. Of those who have graduated between 1 to 3 years, $50.9 \%$ have a part-time contract and $49.1 \%$ a full-time contract. $69 \%$ of those who graduated between 3 and 6 years ago have a full-time contract, although this figure falls slightly and levels out at around $60.4 \%$ for those who have graduated more than 6 years ago.

\section{Place of work}

Almost one in four graduates live outside Spain, mostly in another European country. In its 2015 report, the Instituto Nacional de Estadística (Spanish National Office for Statistics), makes reference to a brain drain running rife among architects, translators and engineers. More to the point here, the report points out that $25.9 \%$ of students who graduated with a degree in Translation and Interpreting in 2009-2010 were working abroad. These figures are in unison with the study by Teichler (2012), which states that university graduates who take part in an exchange programme are three times more likely to work abroad.

\section{Company size}

Graduates mainly work for large companies with more than 500 employees. In fact, according to Teichler's findings (2012), university graduates who have studied abroad tend to work mainly for large or multinational companies. 
Figure 3. Size of companies where graduates work

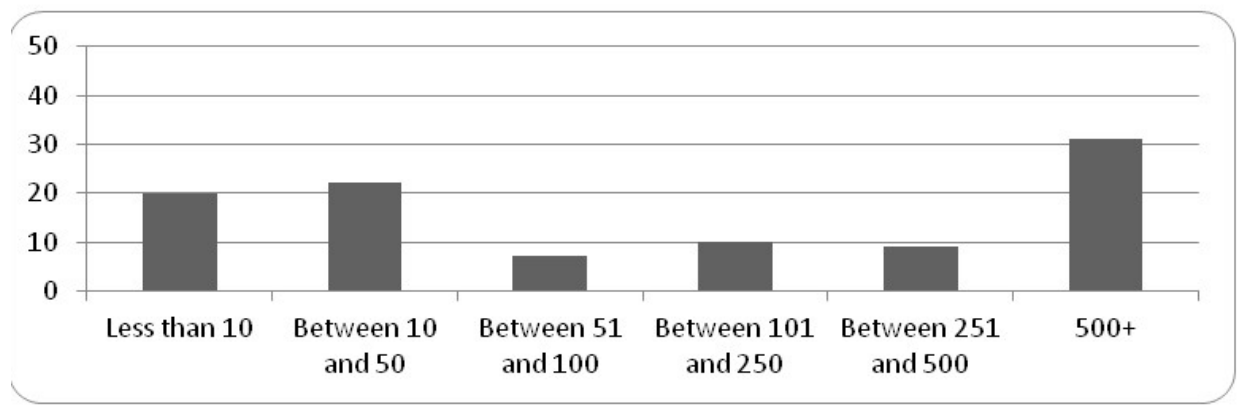

Source: Prepared by the author.

Although not reflected in the data from this study, company size is likely related to the type of work graduates do.

\section{Labour market sector where they work}

From a global perspective the figures show that the teaching sector employs most graduates ${ }^{3}$. However, if we further break down the sectors by gender (see figure 4), you can see here that the percentage of women is much higher $(27.2 \%)$ compared to men $(16.1 \%)$. Translation and Interpreting ranks as the second highest sector which employs graduates in Translation and Interpreting, again with major differences between the genders: men $22.6 \%$, but only $13 \%$ in the case of women.

We can surmise that education institutions and translation companies / agencies which employ the majority of graduates are for the most part small operations with less than 50 employees - some even less than 10. In contrast, while the remaining sectors come under the heading of large companies or organisations: public bodies, hotel industry, industry, media, etc., mentioned earlier. 
Figure 4. Job market sector employed by gender

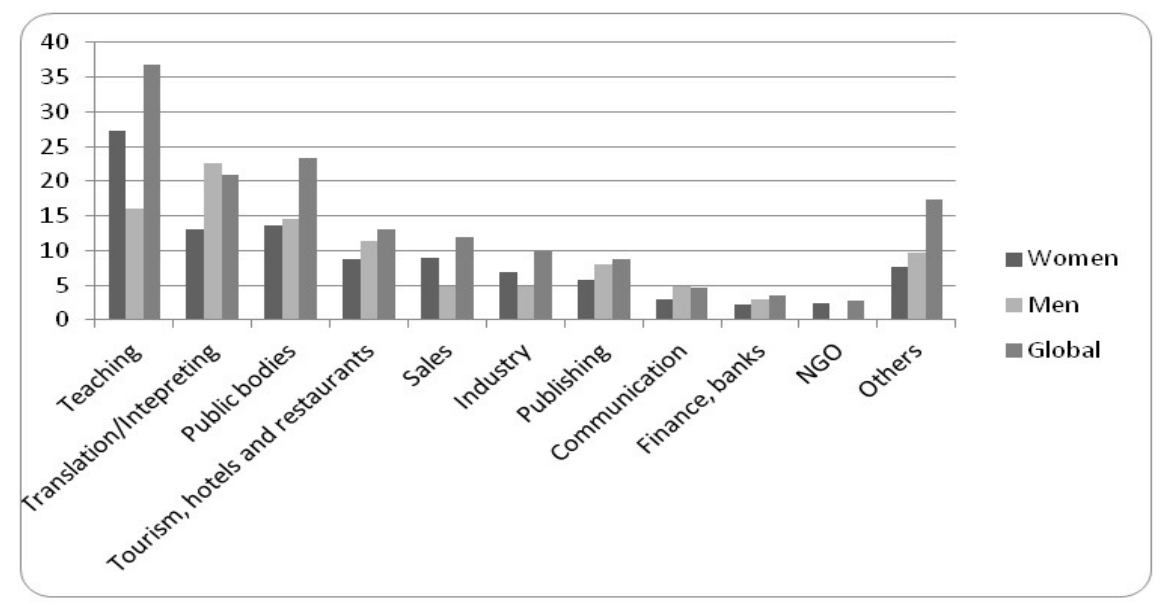

Source: Prepared by the author.

\section{Languages}

From the languages they can study in the FTI degree programme (Arabic, Chinese, English, French, German, Italian, Japanese, Portuguese and Russian), English is the most regularly used by graduates in the work setting (52.38\%). In descending order, this is followed by German (19\%), Chinese (9.5\%), French (7.6\%) and finally Japanese, Portuguese, Italian, Russian and Arabic (ranging from 2\%-4\%). These figures not only highlight the predominance of English in the translation market, but also German (because of the influence of Germany as a major EU force) and Chinese (with China gaining greater weight globally).

\section{Type of professional work}

The main professional tasks performed by graduates are teaching $(57 \%)$, proofing texts $(36.2 \%)$, direct translation (34.9\%) and services in multi-lingual contexts (31.9\%). If we examine the same data along a timeline since the subjects graduated, we can see that teaching accounts for the majority regardless of how long ago they graduated, as illustrated in table 4 below ${ }^{4}$.

Table 4. Type of work

\begin{tabular}{|c|c|c|c|}
\hline < 1 year & 1 - 3 years & 3-6 years & 6-9 years \\
\hline $\begin{array}{l}\text { - Teaching }(66.7 \%) \\
\text { - Services in multi-lingual } \\
\text { contexts }(33.3 \%) \\
\text { - Direct translation }\end{array}$ & $\begin{array}{l}\text { - Teaching }(51.4 \%) \\
\text { - Services in multi-lingual } \\
\text { contexts }(37.8 \%) \\
\text { - Text proofing }(37.8 \%)\end{array}$ & $\begin{array}{l}\text { - Teaching }(54.7 \%) \\
\text { - Text proofing }(37.85 \%) \\
\text { - Direct translation } \\
(37.5 \%)\end{array}$ & $\begin{array}{l}\text { - Teaching }(62.2 \%) \\
\text { - Text proofing }(39.2 \%) \\
\text { - Direct translation } \\
(33.8 \%)\end{array}$ \\
\hline
\end{tabular}




\begin{tabular}{|l|l|l|l|}
\hline$(28.6 \%)$ & - Direct translation & - Services in multi-lingual & \\
& $(36.6 \%)$ & contexts $(32.8 \%)$ & \\
& & - Project management \\
& $(32.8 \%)$ & \\
\hline
\end{tabular}

Source: Prepared by the author.

The following is a more detailed description of the questions related to the professional work done by graduates.

Teaching. As mentioned above, teaching is the main area where graduates work, no matter when they graduated. Most teach English, followed by German, French and Spanish as a foreign language. The education establishments where they work break down as follows:

- Private language schools: $52.99 \%$

- Secondary education schools: $36.57 \%$

- Adult training courses: $33.58 \%$

- Supplementary education: $25.37 \%$

- In-company training courses for professionals: $17.91 \%$

-University: $13.43 \%$

- Spanish state language schools (Escuela Oficial de Idiomas): 11.19\%

Multi-lingual context. $36 \%$ work professionally under the umbrella term "multi-lingual contexts", a category characterised by the wide area it covers (the questionnaire did not identify the languages used in these contexts):

- Organizing trade fairs and events: $30.67 \%$

- Secretarial: $28 \%$

-Language advisory services: $13.4 \%$

- Tourism: $14.67 \%$

- Hotel staff: $10.67 \%$

- Language level assessment of job candidates: $10.67 \%$

- Search for new markets and businesses: $9.33 \%$

- Language audits: $1 \%$

- Other - high ranking -, such as management tasks or coordination in international settings: $8.6 \%$

- Others - low ranking -, such as customer support service: $12 \%$

Text proofing. The main areas where they proof texts are: newspaper / magazine publications (articles, news, press releases etc.), technical (instruction manuals, software), scientific, legal and marketing. In order of most to least common source languages, these are English, Catalan and Spanish, while for target languages these are Spanish, Catalan, and to a small degree, English. 
Direct translation. The main topic areas in which they translate are:

- Marketing: $42.8 \%$

- Technical: $37.3 \%$

- General: $36.2 \%$

- Software, websites, administrative and legal - in order of importance varies from 30\%-20\%

- Non-literary editorial texts, subtitling, scientific and economic: ranging in order of importance from $20 \%-10 \%$.

- Other specialised areas: translating video games, voice-over and transcribing.

Figure 5. direct translation

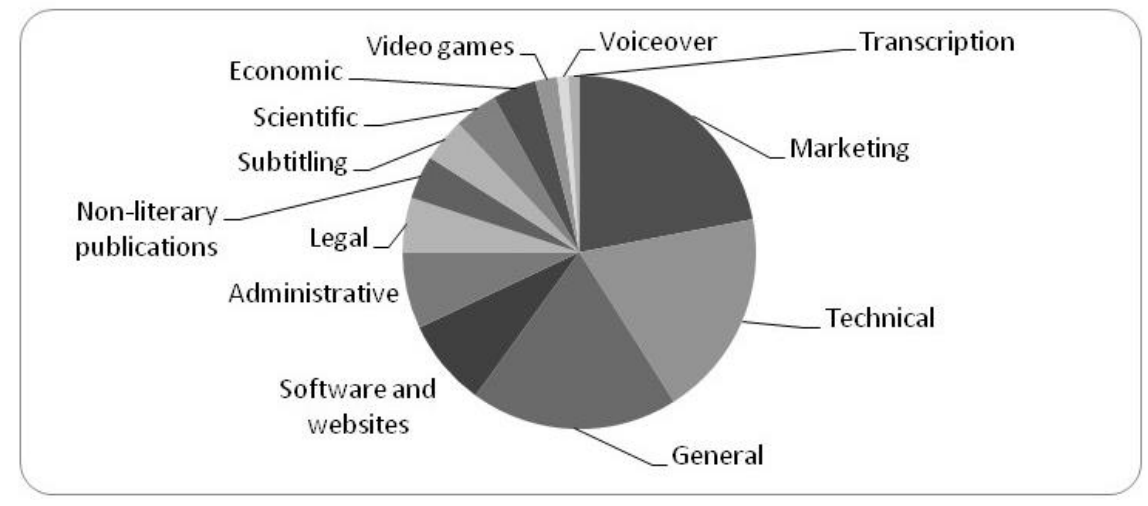

Source: Prepared by the author.

The most common language pair in direct translation is English-to-Spanish, however, the most common combination for technical and administrative texts is German-to-Spanish. The principal source languages they work with are: English, German and Spanish and to a lesser degree French, Japanese and Chinese, while the most common target languages are Spanish, Catalan and English.

Project management:. This is usually a job which involves various languages, with English being the most recurrent. The survey reveals that graduates who have taken other bachelor degrees in addition to translation and interpreting, are much more likely to be involved in project management, but I am inclined to think that respondents may not have understood the question correctly, which referred only to managing translation projects.

Other low-ranking work: inverse translation, interpreting, post editing and editing.

Below is a breakdown of the kind of work performed in these minority areas, although there were few cases in this study: 
- Inverse translation. $10.7 \%$ work on inverse translations. There is very little variety in terms of specialised text areas. The percentage of time devoted to inverse translation varies a good deal: we find some subjects who spend between 0 and $25 \%$ of their time, while others dedicate most of their time (between $75 \%$ and $100 \%$ ) on inverse translation.

- Interpreting. $8.7 \%$ interpret. Of those, $48 \%$ work in liaison interpreting, followed by simultaneous interpreting (28\%) and telephone interpreting (24\%). While the type of organisation or body they commonly work for varies, the common denominator is that they are all in the public sector, particularly in the following areas: social services, education centres, penal institutions and police stations.

- Post-editing. $8.7 \%$ work on post-editing tasks.

- Text editing. Of the $8.3 \%$ who work in this area, $50 \%$ are involved in typesetting, while $37.5 \%$ noted text aligning and $25 \%$ creating terminology bases.

\subsection{Factors associated with having a professional career related to studies}

Graduates consider their professional work to be quite closely related to their studies (2.64), when asked to rank this on a scale of 1 (not related) to 4 (very related). In addition, with the passing of time, they find jobs more related to their studies as shown in table 5 below.

Table 5. Studies related to job over time

\begin{tabular}{|c|c|c|c|}
\hline$<\mathbf{1}$ year & $\mathbf{1 - 3}$ years & $\mathbf{3 - 6}$ year & 6-9 year \\
\hline Average $=2.39$ & Average $=2.63$ & Average $=2.63$ & Average $=2.76$ \\
\hline
\end{tabular}

Source: Prepared by the author.

\section{Academic trajectory}

Having followed other study programmes has a slightly positive impact (2.63 on a scale of 1 to 4) ${ }^{5}$ when it comes to finding a job related to their studies, especially for those who have taken degrees in journalism and communication or philology, followed by those who have studied tourism or social sciences. 
Figure 6. Relationship between studies and work

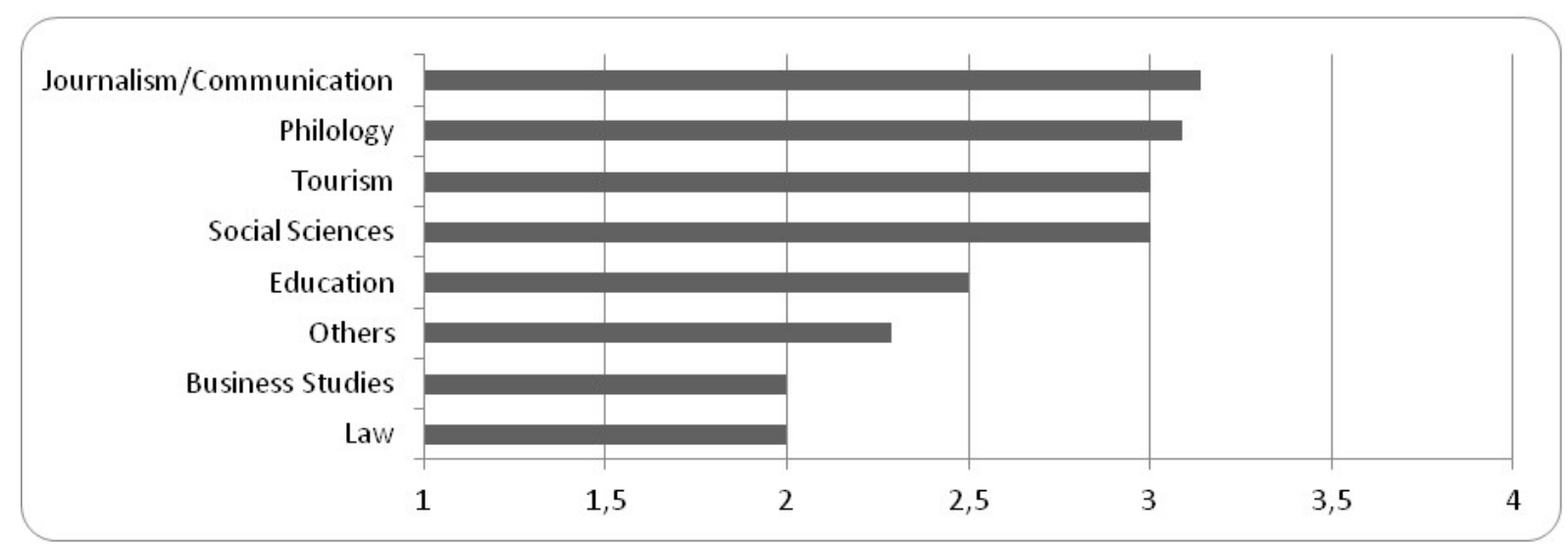

Source: Prepared by the author.

Generally speaking it seems that those who specialise end up performing tasks for which they were trained, in fact, comparing the averages shows that those who have specialised state that their job and studies are quite related (2.98), which is higher than for those who only studies a degree in Translation and Interpreting (2.64).

Having an M.A. has a bearing on working in a job more closely related to their studies. As pointed out earlier in section 2.1., the Masters are mainly specialist areas in the field of translation and interpreting, although there are some cases which are associated more with international relations and company management than translation, such as sales.

- Language advisory services and proofing. Those with an M.A. mainly work on text proofing tasks (68\%), teaching (48\%) and direct translation (40\%). They work with Catalan and, to a lesser degree, Spanish, or with the English-Catalan language pair. As regards kinds of texts, these are novels, text books, general publications and the journalistic contents in various media.

- Audiovisual translation. The most common tasks are related above all to direct translation (50\%) and proofing (45\%), although also with project management (31\%) and teaching $(31 \%)$. The direct translation tasks are audiovisual translations and account for $40.9 \%$ of the work done in this area. $31.8 \%$ work on localisation (software, video games and websites). Teaching is mainly in private language schools and secondary education. 
Project management is generally related to localisation or with technical projects (more specialized areas).

- Tradumatics. The main tasks are direct translation (57.8\%), proofing (52.6\%) and project management $(42.1 \%)$. Direct translation in particular embraces technical, administrative, localisation and marketing texts, which also crop up in areas of project management.

What needs to be investigated here is whether the professional jobs graduates are doing really require mastery of the competences acquired in a Masters or a second bachelor's degree, or are cases of overeducation.

\section{Reconciling studying and working}

$27.2 \%$ of graduates surveyed work and study at the same time. Firstly, one can observe that there is a slight, but statistically significant, correlation between working and studying and having a studies-related profession (Pearson correlation coefficient of 0.171, level of significance $p=0.01$ ), but also a somewhat stronger negative correlation (Pearson correlation coefficient of -0.219 , level of significance $p=0.01$ ). This indicates that working while studying for a degree penalises academic performance in some cases.

Secondly, those who work while studying find jobs which are more related to their degree only when the job itself is related to their studies (2.96). While those who had jobs unrelated to their degree during their studies $(41.5 \%)$ find jobs less related to their studies (2.45), while those who did not work while studying obtained jobs that were quite closely related (2.62).

\section{Study abroad exchanges}

Having studied abroad does not influence finding a job related to one's studies, although having pursued two or more study abroad exchanges does have a slight influence this group of graduates rate this relationship above 2.8 on a scale of 1 to 4 . 
Figure 7. Number of study abroad exchanges

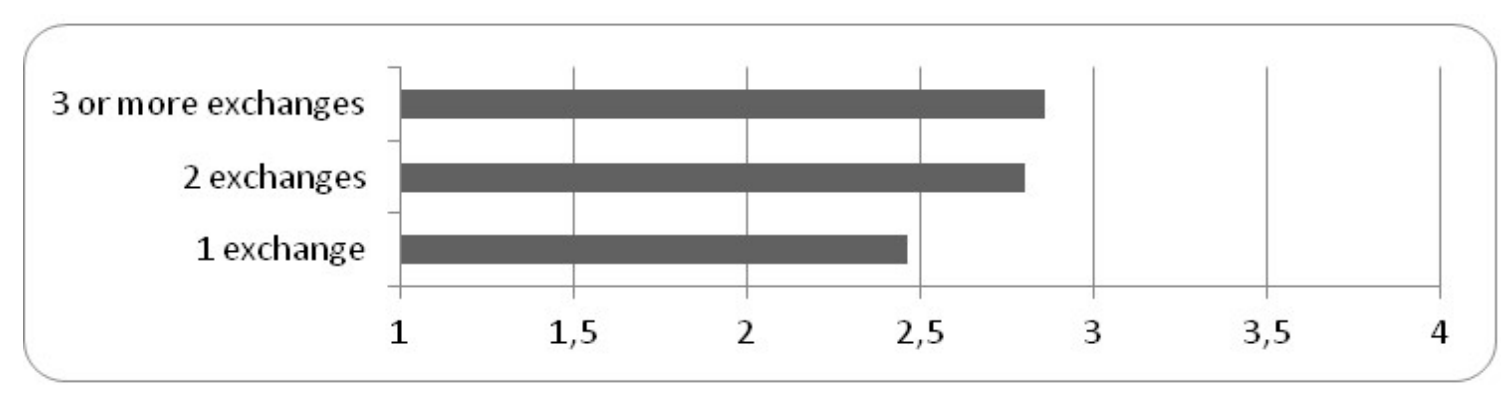

Source: Prepared by the author.

Concerning studying abroad, Iriondo (2016) poses the question of whether those who have participated in two or more study abroad exchanges found jobs related because of this experience or due to other non-observable characteristics, such as motivation, abilities or family background.

\section{University internships}

Having taken the internship option as part of the FTI's B.A. in Translation and Interpreting has a positive effect when it comes to finding studies-related work: those who did rated this 3.04 on a scale of 1 to 4, while those who did not returned a lower rating of 2.6. This could well be attributed to what Hergert (2009) points out, namely that internships help to breach the psychological gap between university and the job market, raise self-esteem in graduates and as a consequence they are more proactive.

\section{Tasks performed in current job}

If we examine how related graduates see their work and studies on the basis of the tasks they perform in their current job (see figure 8), we can see that those most closely related are: direct translation (3.33) and post editing (3.32), followed by text proofing (3.04), managing projects and text editing (2.89). In contrast, the tasks they consider least related to their studies are interpreting (2.47), working in multilingual contexts (2.48), inverse translation (2.63) and teaching (2.72). It should be noted, however, that there is no task in which they perceive the relationship with their studies to be minimal.

Working in multilingual contexts is very diverse (see 2.2) and draws upon a wide range of knowledge areas, so it is only logical that graduates feel it is not particularly linked 
to their studies. However, it is surprising that they consider interpreting and inverse translation as unrelated since both are required subjects in the FTI Translation and Interpreting B.A. degree programme.

Teaching is a case apart because the FTI B.A. programme does not include any subjects on language teaching methodology, yet even so students consider that it is positively related to their studies with a rating of 2.72 over 4 . We could surmise that they have this perception because what they are really rating is the level of language skills they reach in the course of their university studies.

Figure 8. Job / studies relationship according to professional tasks performed

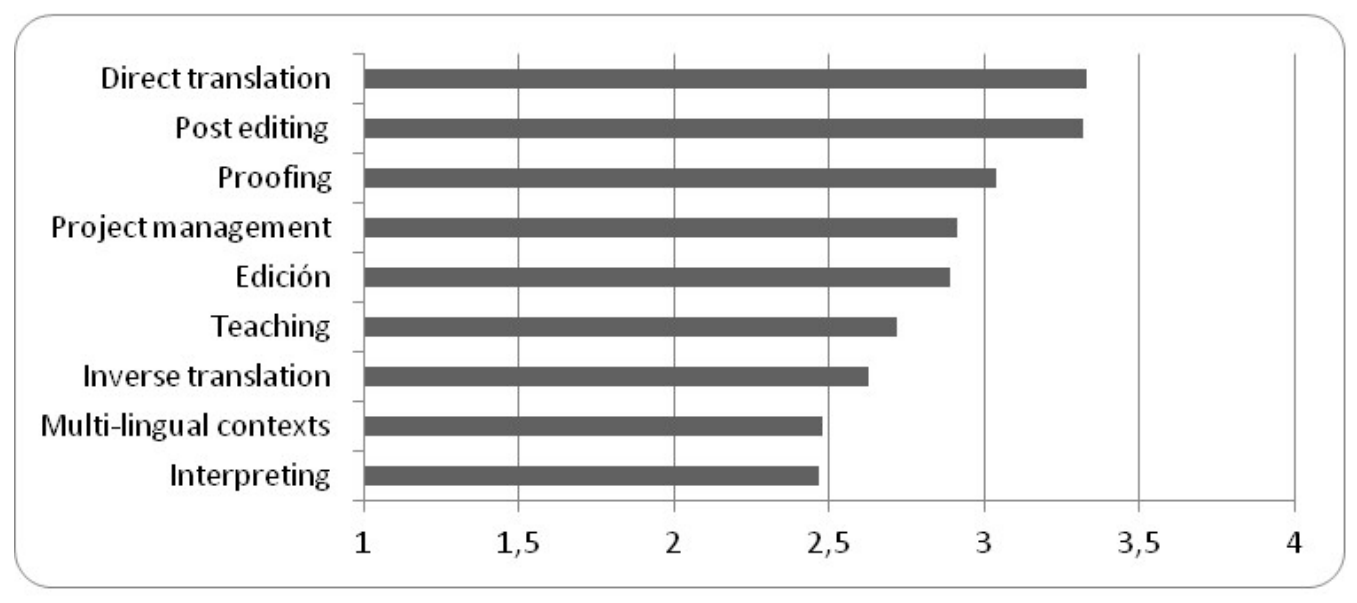

Source: Prepared by the author.

\section{Languages used in current job}

As regards the languages graduates use in their current job, the majority of those who state that they have jobs closely related to their studies are working with languages which they studied during their undergraduate degree, as illustrated in table 6 below.

Table 6. Job / studies relationship according to languages used in their profession

\begin{tabular}{|c|c|c|}
\cline { 2 - 3 } \multicolumn{1}{c|}{} & $\begin{array}{c}\text { Job little or unrelated } \\
\text { to studies }\end{array}$ & $\begin{array}{c}\text { Job quite or very related } \\
\text { to studies }\end{array}$ \\
\hline $\begin{array}{c}\text { Do not work with } \\
\text { languages studied }\end{array}$ & $12.9 \%$ & $15.1 \%$ \\
\hline $\begin{array}{c}\text { Work with languages } \\
\text { studied }\end{array}$ & $22.6 .7 \%$ & $49.5 \%$ \\
\hline
\end{tabular}

Source: Prepared by the author. 
Factors associated with salary level

As pointed out in section 2.2., the salary level from the sample is around 3.18 on a scale of 1 to $6,{ }^{6}$ that is, between $€ 12,000$ and $€ 18,000$ per annum.

\section{Academic trajectory}

Having studied other undergraduate degrees can be linked to slightly higher salaries, even more so than having studied an M.A. Those with the highest salaries took degrees in business studies and either communication / journalism (although there is one subject who studied Law which distorts the results), then, moving down the salary scale we have those who studied social sciences or philology. Figure 9 below gives the income levels of graduates according to their academic trajectory.

Figure 9. Average earnings

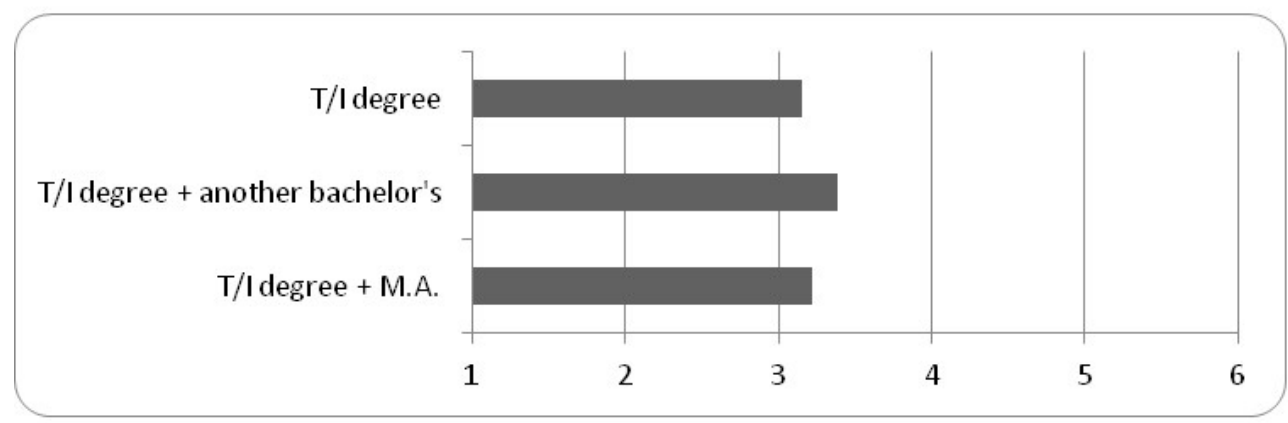

Source: Prepared by the author.

Figure 10. Average earning by category according to other undergraduate studies

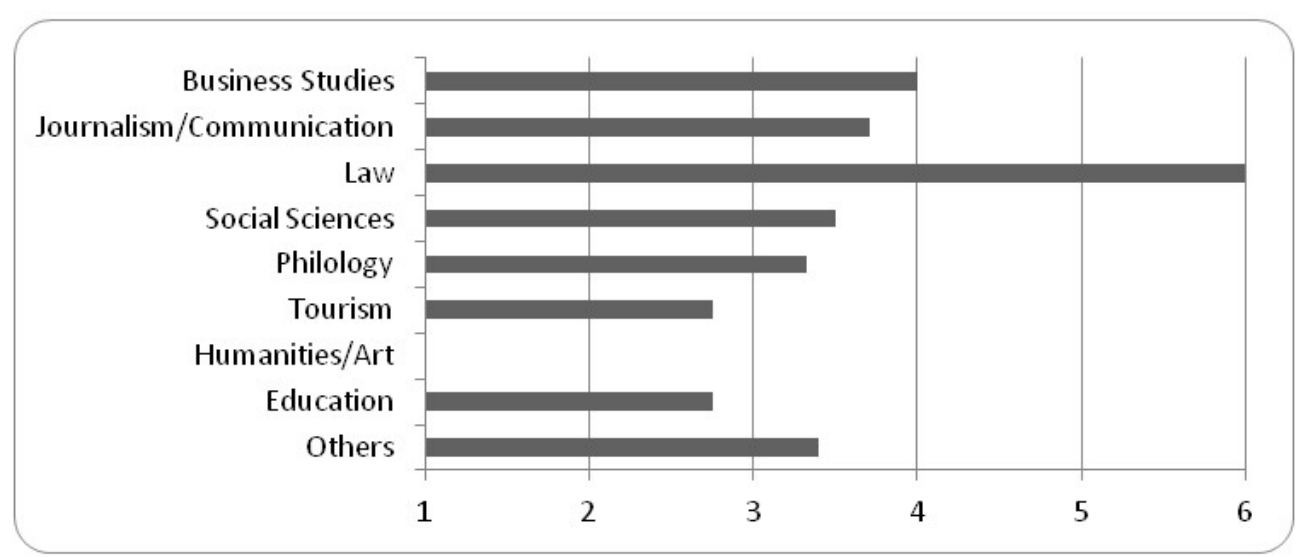

Source: Prepared by the author. 
Figure 11. Average earnings according to other Masters

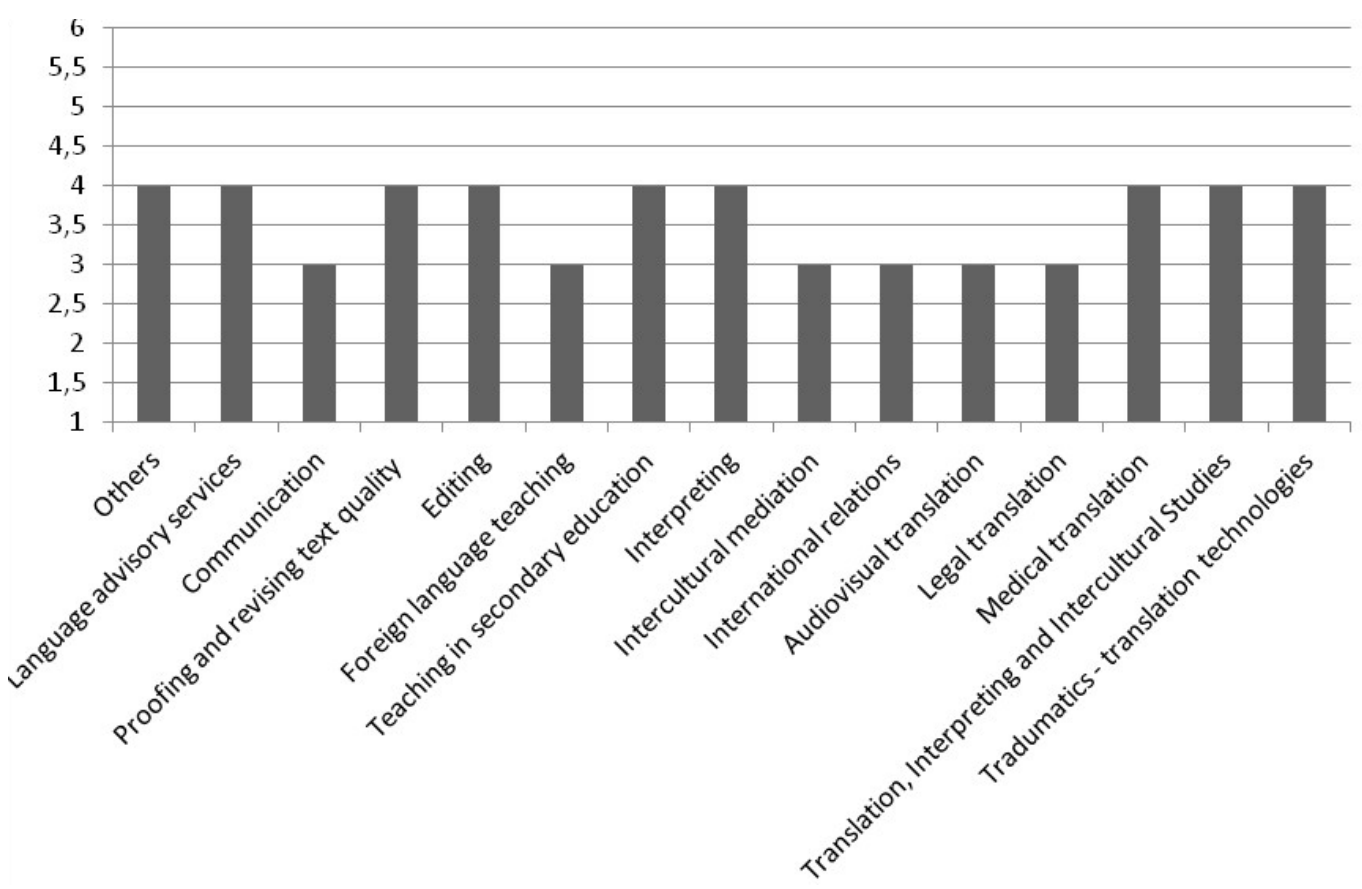

Source: Prepared by the author.

\section{University internships and study abroad exchanges}

Internships have a slight influence on earnings of those who are employed: 3.28 over 6 as opposed to 3.7 for those who did not take up the internship option.

Study abroad exchanges only influence earnings when the subject had participated in two or more, 3.2 and 3.58 respectively. On this issue, Rodrigues (2013) points out that going on an international student exchange only increases earnings by $3 \%$, so that the income level occurs when subjects significantly distinguish themselves from the rest with more than one study abroad exchange.

\section{Reconciling studying and working}

Having worked while studying has a relatively small impact on graduate earnings, since those who work in areas related to their studies is around 3.18, those who work in unrelated areas is around 3.32, and those who do not work while studying is slightly lower at 3.01. 


\section{Size of company}

Graduates who work in medium and large companies or organisations earn slightly more than those who work in companies with less than 50 employees.

Figure 12. Average current earnings according to company size and number or employees

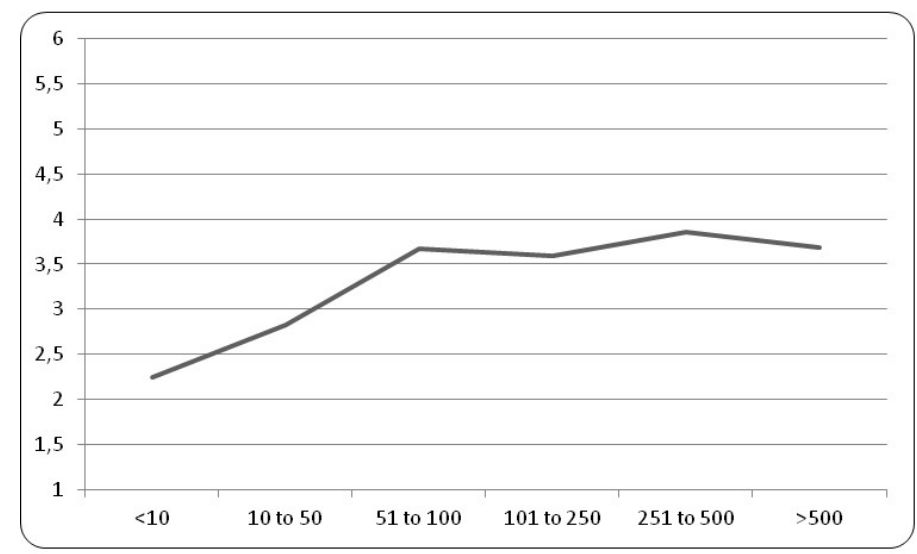

Source: Prepared by the author.

It is only to be expected that the size of the company can be identified as a factor associated with higher income since large companies have higher rates of productivity than small companies.

\section{Professional job}

Although there are no significant differences in graduate earnings based on their professional job, text editing and post editing appear to be the better paid. Teaching is paid lowest, followed by interpreting (almost certainly because this kind of work is intermittent which the subjects have only done sporadically). 
Figure 13. Average earnings according to professional tasks performed

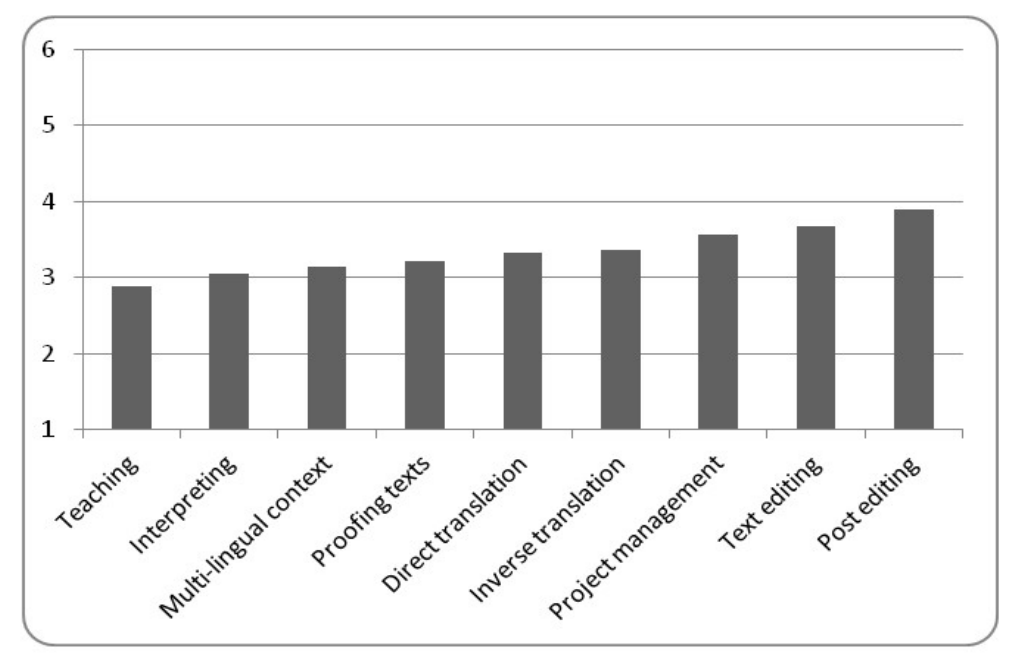

Source: Prepared by the author.

\section{Job tasks related to studies}

If we look at the relationship between work, studies and income, we can see that graduates earning less than $€ 9,000$ per annum are those whose jobs are least related to their studies. However, those who earn more are not necessarily those whose jobs are most directly related to their studies.

Figure 14. Work/studies relationship according to earnings

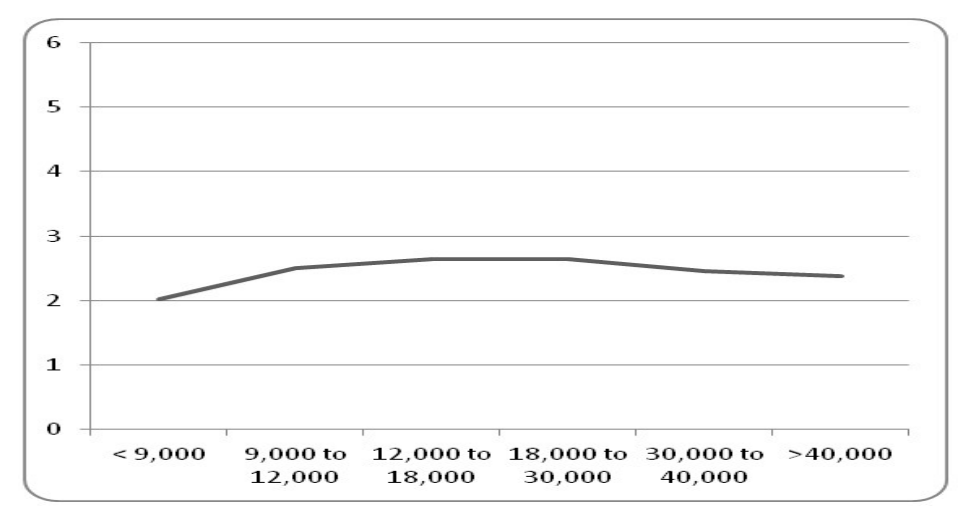

Source: Prepared by the author.

Two factors may help to explain the curve in figure 14 above. First, those who earn less than $€ 9,000$ have graduated more recently and, therefore, are working in jobs less related to their studies. Second, at the other end of the scale, the group who earn more than $€ 30,000$, is where we find the highest proportion of graduates who have taken other degree courses. 
Salary differences according to the main working languages (English, French, German and Chinese) are minimal: in English the average is 3.54, German 3.52 and Chinese 3.45. In French this is slightly lower (2.92), while for other languages there are no significant differences.

\subsection{Types of degrees and the job market}

As illustrated in the bivariate analysis data analysis in the previous sections, different aspects of the subjects' academic background appear to be related to some degree with aspects of the current position of graduates in the job market (tasks performed, earnings, studies...). This section provides an analysis of the latent classes with the following 10 variables:

a) Academic background

- Has studied another bachelor degree (Yes/No)

- Has studied an M.A. (Yes/No)

- Reconciled studying and working, and the job was related to the B.A. programme (Yes/No)

- Number of study abroad exchanges (none, 1, 2, or more)

- Year of graduation (2004 to 2014)

b) Position in the job market

c) Earnings (6 tracks, see section 2.4)

- Type of employment relationship (work for third parties, self-employed, combination, own company)

- Work/studies relationship (none, some, quite a bit or a lot)

- Percentage of work dedicated to language services (5 tracks of 20\%)

- Currently unemployed (Yes/No)

Latent class analysis classifies individuals in homogenous groups according to their characteristics in each variable observed. This allows for identifying the latent groups and the characteristics which make up their identity, in other words, which latent models there are in the data as a whole. Figure 15 illustrates the profile of each group according to their probability of being associated with certain variables. This gives a total of six groups which are given below. 
Figure 15. Probability of forming part of different model variable categories

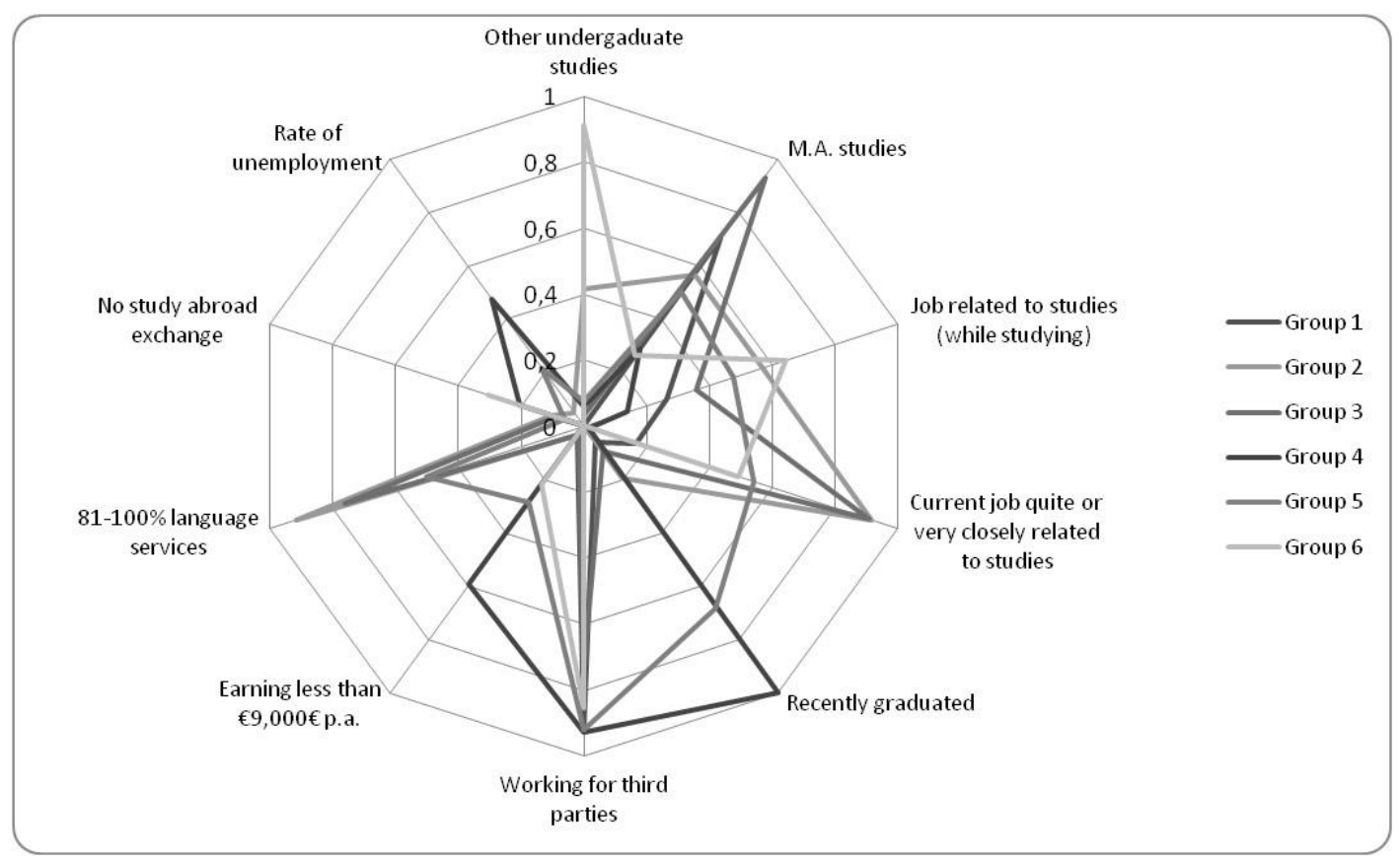

Source: Prepared by the author.

Group 1 - Graduates who have an M.A. and a job which is not closely related to their studies

The two characteristics of this group are: having an M.A. and working in jobs perceived as little or unrelated with their studies. These are students who graduated before 2011, work for third parties, have medium-high salaries, and for which the unemployment level is low.

Figure 16. Group 1

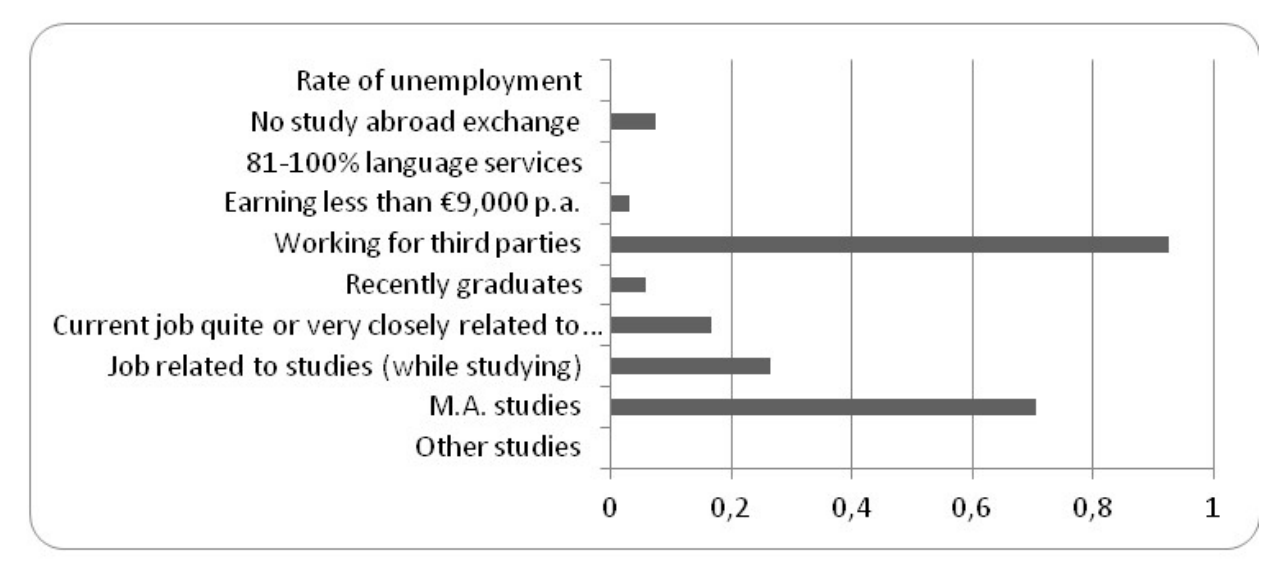

Source: Prepared by the author. 


\section{Group 2 - Graduates who are self-employed}

Being self-employed characterises one group of graduates, regardless of when they graduated. All these subjects see their professional work as being closely related to their studies, over and above the average for the other groups. This consists almost entirely of providing language services.

Figure 17. Group 2

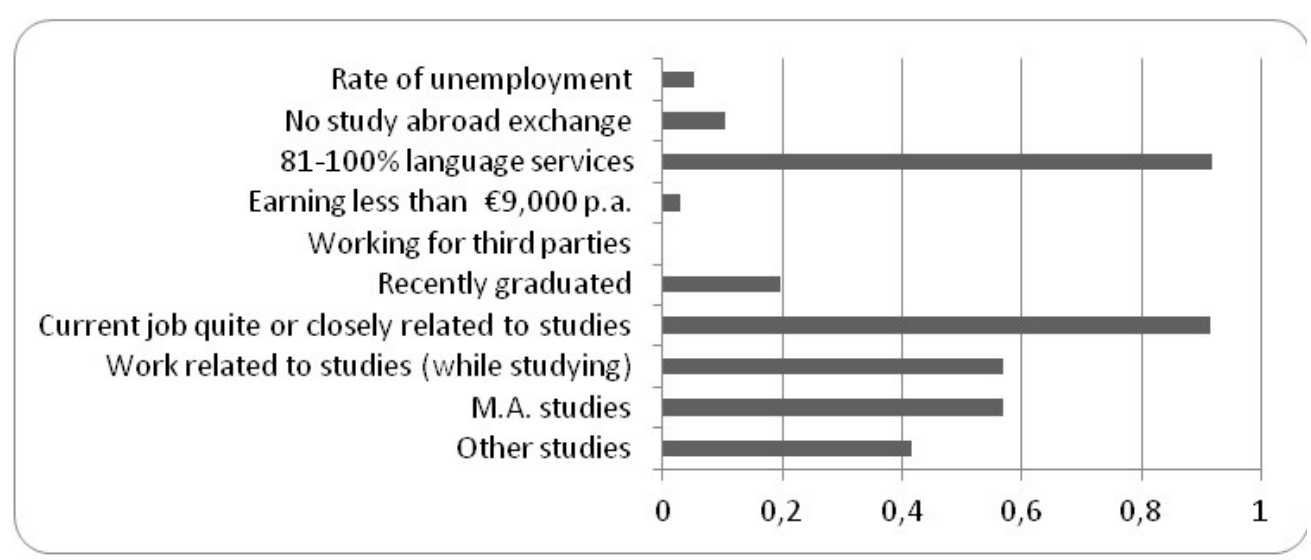

Source: Prepared by the author.

Group 3 - Graduates with an M.A. and have a job which is quite closely related to their studies

In direct contrast with group 1 who have an M.A. and regard their job as being little related to their studies, group 3 comprises graduates with an M.A. but do consider their job to be related to their studies. Their professional work is related to providing language services and working for third parties.

Figure 18. Group 3

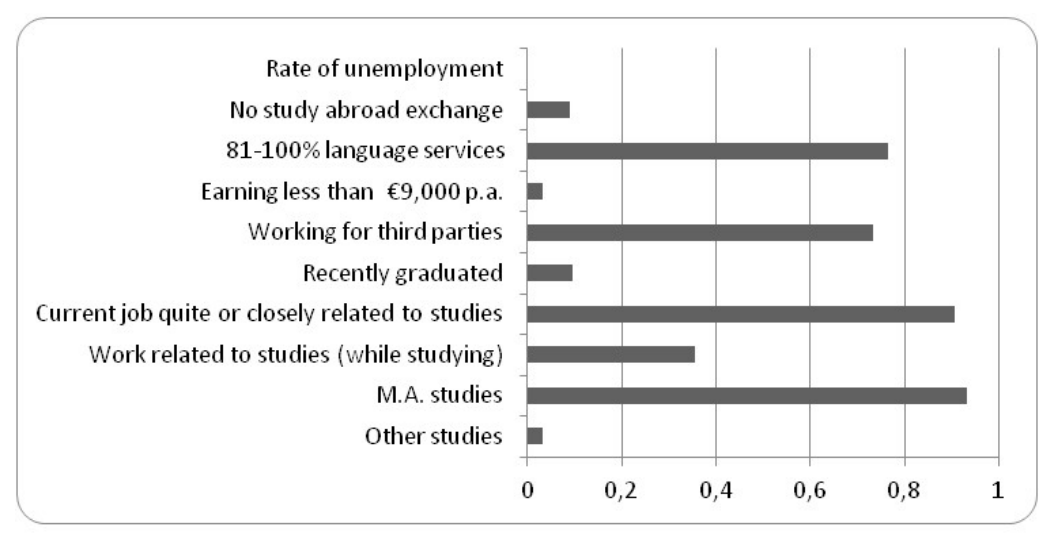

Source: Prepared by the author. 
The characteristic features of this group are having graduated recently and not having taken another B.A. or M.A. These work for third parties, although this is also the group in which there is the highest rate of unemployment.

Figure 19. Group 4

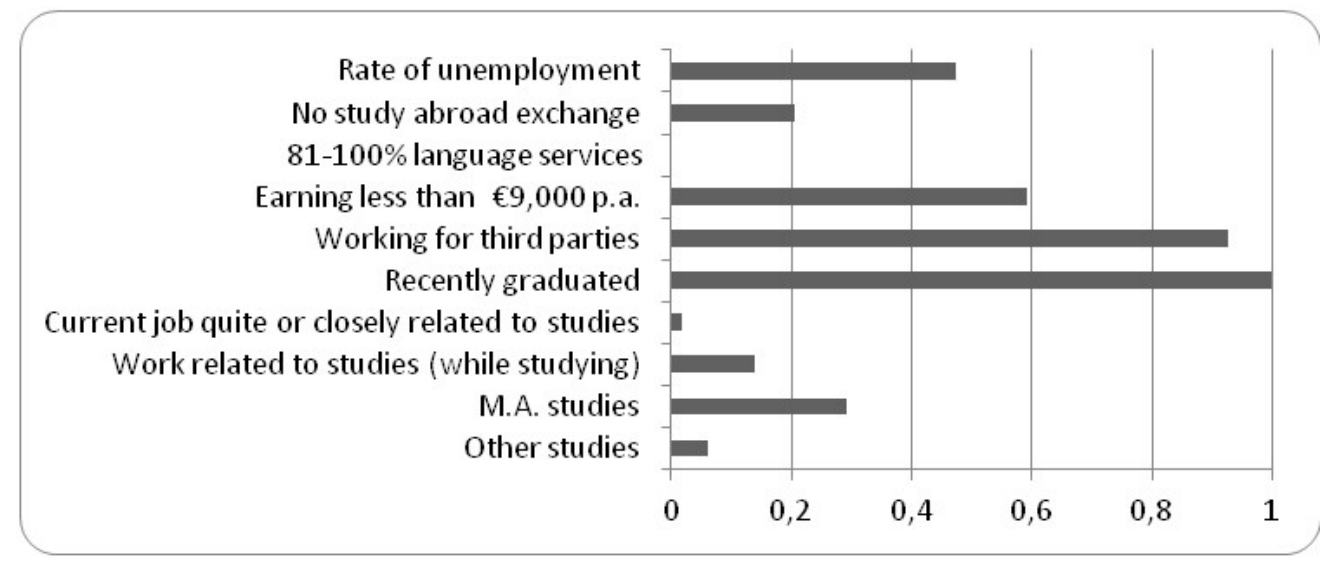

Source: Prepared by the author.

Group 5 - Recent graduates with a job minimally related to their studies

This group comprises those who have recently graduated, mainly work for third parties, have jobs minimally related to their studies and who also have an M.A.

Figure 20. Group 5

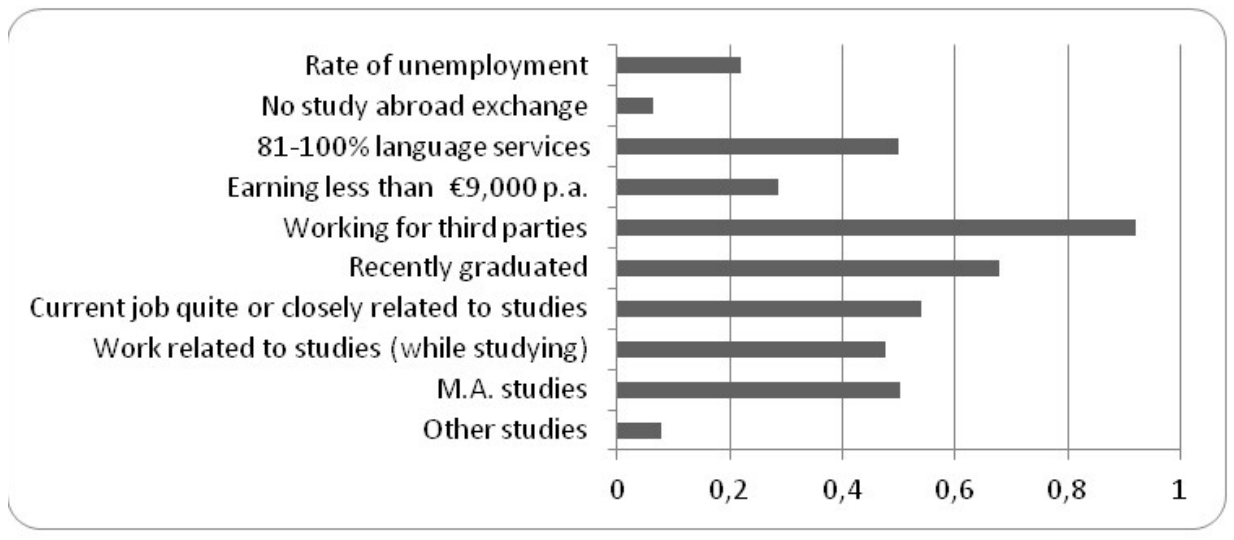

Source: Prepared by the author. 
These are graduates with medium to high earnings who feel there is some correlation between their work and studies, although they consider this to be insufficient. Furthermore, these worked while they were studying and this job was related to their undergraduate degree.

Figure 21. Group 6

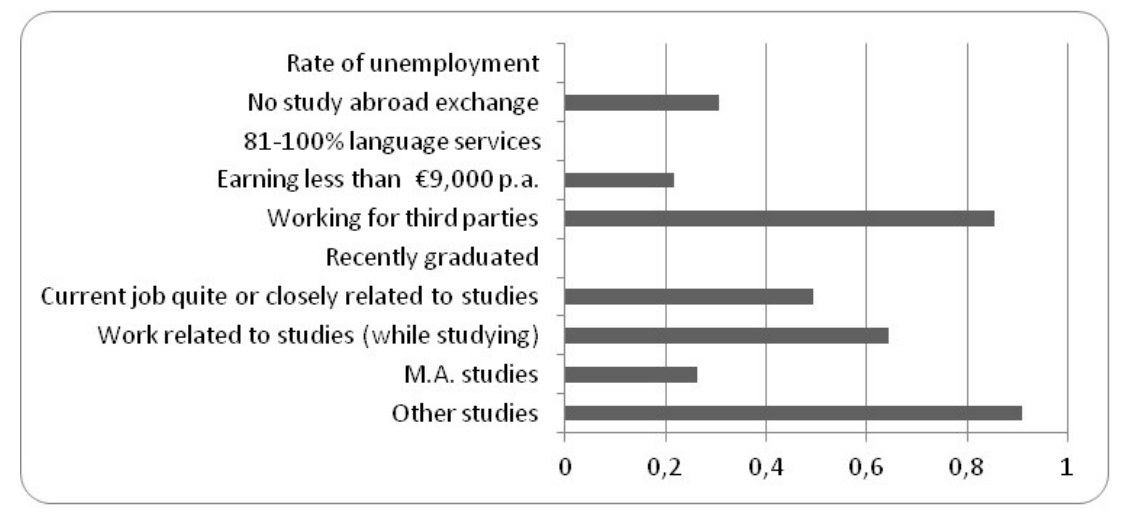

Source: Prepared by the author.

Based on observations of these groups, it can be stated that:

- Specialised training through an M.A. leads to a higher income.

- Of those with a Masters, there is a group who have jobs perceived as quite closely related to their undergraduate degree but another who see their jobs as being unrelated to their bachelors. This stresses the fact that it is the post B.A. specialization which determines the job they take up.

- Becoming self-employed is one path to a professional job which is completely related to one's studies.

- Job conditions improve with time in the job market, although there are some subjects who find good positions shortly after graduating.

\section{Discussion}

The results show that the level of employment among students graduating in Translation and Interpreting at the Universitat Autònoma de Barcelona is very high, at around $85.5 \%$. It is evident that the job market in translation and interpreting, far from being saturated, is growing, as also illustrated by the figures published by the Spanish National Institute of 
Statistics in 2015. However, seen from the opposite angle, there is the question of the remaining $14.5 \%$ of graduates who are unemployed. It would be useful to ascertain the reasons why; whether due to the current economic climate or voluntary unemployment in order to acquire more specialized skills, spend time abroad to improve their language skills or maternity leave.

A striking feature is that one in four graduates live abroad. This demonstrates that graduates tend to make their way in other EU countries in the face of an overall unemployment rate of $20.8 \%$ in Spain - which rises to $25.5 \%$ among young people, 15-24 year-olds (OECD 2016). This should be a warning for governments given the implication that the Spanish state invests in training young people, but once trained they face the lack of professional opportunities and they leave their country in search of job opportunities.

It should be noted that while the employment level among graduates in Translation and Interpreting is high, their income level is not exceptional: only $10 \%$ earn more than $€ 30,000 \mathrm{a}$ year. This needs to be seen in the light of the average salary in Spain, which is currently $€ 26,701$ according to the Spanish National Institute of Statistics, and also includes people with and without university studies.

Perhaps the earnings prospects which graduates are faced with in Spain is the reason why three out of four graduates opt for extending their academic trajectory, mostly with an M.A. or graduate course. Having studied abroad more than once or taken a second undergraduate degree has a positive influence on level of earnings, even more than having an M.A. Nevertheless, an M.A. specialising in an area of Translation and Interpreting means working professionally in areas more related to their studies. Whatever the case, overeducation increases a person's level of competitivity, whether this refers to their income level or their job satisfaction. On this theme, Planas (2011) points out that overeducation ends up causing a knock-on supply effect, that is, the more training graduates have the more training employers are going to ask for, even if in reality they do not need employees with so much training and so many competences.

I would like to underline the importance of study abroad exchanges, holding an M.A. or having taken graduate courses as regards labour market insertion, although it would be necessary to research into the impact of individual traits such as attitude and personality. Regarding the income level of graduates, it would be useful to repeat this study with the same sample group in a few years in order to find out whether the low- income level is short term, 
if it improves after 10 years working professionally, or in fact reflects the typical salary level in the translation and interpreting job market.

It is possible that the economic crisis, along with the fall in the number of grants, hikes in university fees and higher cost of living, have contributed to the fact that one in four graduates have had to reconcile working with studying. This is a variable which has a slight positive effect on finding a job related to their studies, but has no significant bearing on level of earnings. The percentage who work for themselves, or have at some point during their professional career, is relatively high compared to graduates from other degrees, although it is still very low if we take into account that most of the translation jobs are externalised and done by freelances. The fact that there are not more graduates in this category could well be due to either the economic crisis in Spain - which has hit self-employed professional sector hard, or lack of entrepreneurial training during their degree.

The results of this study highlight the range of tasks graduates end up doing, corroborating Kuznik's results (2016, 2011, 2010 and 2007). Following on from this, if teaching and working in multilingual contexts, along with all the range of tasks they entail, are the main professional jobs taken up by graduates in Translation and Interpreting, this begs the question as to whether a debate would be pertinent on the need to adapt degree programmes to this job market situation and include other competences, more closely linked to international relations, administration, communication, secretarial work, applied languages or foreign language teaching methodology.

Finally, it has to be stressed that one of the survey questions was related to the text genres. The aim was to try and determine whether there are any typical text types for each language pair so that this information could be incorporated into the undergraduate degree programme. Unfortunately, this was not classified as a required answer question, so it has not been possible to collect enough responses to this question to obtain significant data.

\section{Conclusions}

As mentioned in the introduction, surveys on graduates are a general indicator of a university's achievements.

This study provides a reasonably comprehensive view of graduates with a B.A. in Translation and Interpreting from the UAB. Given the criteria proposed by Teichler (2005), it 
can be seen that labour market insertion of UAB graduates is positive: there is a smooth transition from studying to working since the employment rate of recent graduates is relatively high; the proportion of unemployed is low; and the percentage of graduates with a job related to their field of study is high. So, a degree in Translation and Interpreting at the UAB does conform to the role which the EHEA attributes to higher education institutions, namely, to train graduates who are easily employable in the job market. However, the results given here should be treated with caution and the current economic situation in Spain taken into account.

Knowing to what extent and in which professional tasks graduates work is fundamental in order to assess how well the undergraduate degree programme meets job market demands, since higher education is expected to help students acquire competences which are potentially important in the work context. Along these lines, it is unfortunate that it was not possible to obtain sufficient information concerning the text genres graduates work with. This would have been key information to determine which text genres should be worked with in the classroom for each language pair and area of specialisation (PACTE, 2018).

Including recently graduated students has proved a valuable dimension in this study as it has allowed for analysing the development of graduates depending on the length of time since they graduated. As these are results from only one university, a similar study would need to be carried out with graduates from other universities and from other economic climates. It is also necessary to collect information about how long graduates stay in each job and the paths followed to find a job, which would help to determine whether universities should offer training and orientation on job seeking strategies in general and self-application and self-employment in particular (Galán-Mañas, 2017). The need to repeat this study has to be underlined so that time-related indicators can be extracted and the professional career trajectories of undergraduates can be analysed.

Future research should also study whether certain personal and entrepreneurial skills (communication, self-esteem, leadership, etc.) influence job market insertion of graduates. Likewise, it is essential to assess whether the question of overeducation mentioned here, can really be considered as such and that graduates are overqualified for the job market demands, or whether, such qualifications are really necessary to perform professional tasks.

As a final comment, perhaps we should be opening up dialogue about whether degrees in Translation and Interpreting need to be less specialised and oriented more towards 
transversal spheres such as applied languages and international relations, disciplines which translators and interpreters have invested all their efforts to move away from in the last few decades.

\section{Acknowledgements}

I would like to thank the UAB's School of Translation and Interpreting for financing this study. I would also like to express my deep gratitude to X. Guijarro, the technician who collected the data, and to J. Penedés, L. Santamaria and W. Neunzig for their valuable suggestions during the design of the questionnaire. I would also like to thank to A. Kuznik for her valuable comments on the article.

\section{Resumo}

Este artigo tem como objetivo apresentar os resultados de um estudo de mercado sobre a inserção laboral dos graduados em tradução e interpretação da Universitat Autònoma de Barcelona (UAB), Espanha. O estudo analisa a trajetória acadêmica, a situação de trabalho e os fatores que influenciam na obtenção de um trabalho relacionado aos estudos e com o nível salarial dos graduados de 10 cursos acadêmicos. Os resultados mostram que há um número significativo de graduados empregados com um nível salarial médio. Observa-se também que grande número de sujeitos optou por continuar sua trajetória acadêmica no final do curso. A sobreformação influencia positivamente, juntamente com as estadias no exterior, o nível salarial. A atividade profissional dos egressos é muito diversa e, de alguma forma, aproximase mais da transversalidade típica dos estudos de línguas aplicadas e das relações internacionais, do que da especificidade dos estudos em tradução e interpretação.

Palavras-chave: Inserção laboral. Graduados em Tradução e Interpretação. Estudo de mercado. Tarefas profissionais. Serviços linguísticos.

\section{Notes}

${ }^{1} \mathrm{http} / / /$ www.aqu.cat/estudis/ilaboral_2014.html\#.WINQMt_iaUk

${ }^{2}$ The sum of the percentages exceeds $100 \%$ because some respondents gave multiple responses.

${ }^{3}$ The sum of the percentages exceeds $100 \%$ because some respondents gave multiple responses.

${ }^{4}$ The sum of the percentages exceeds $100 \%$ because some respondents gave multiple responses.

${ }^{5} 1=$ none, $2=$ a little, $3=$ quite a bit and $4=$ a lot

${ }^{6} 1=$ less than $€ 9,000 ; 2$ = from $€ 9,000$ to $€ 12,000 ; 3$ = from $€ 12,000$ to $€ 18,000 ; 4=$ from $€ 18,000$ to $€ 30,000 ; 5=$ from $€ 30,000$ to $€ 40,000 ; 6=$ more than $€ 40,000$

\section{References}

ANECA Libro blanco. Título de grado en traducción e interpretación, 2004. Available at: https://www.ehu.eus/documents/1690128/1704927/libro_blanco_Traduccion_Interpretacion_ ANECA.pdf. Accessed: 15 Sep. 2018. 
BARONE, C. and ORTIZ, L. Overeducation among European University Graduates: a comparative analysis of its incidence and the importance of higher education differentiation. Higher Education, 61(3), 325-337, 2011.

GALÁN-MAÑAS, A. Programa para la mejora de la empleabilidad de los egresados en Traducción e Interpretación. Un estudio de caso. Conexão Letras, 12(17):153-171, 2017.

HERGERT, Michael. Student perceptions of the value of internships. Business Education, 2(8):9-14, 2009.

INSTITUTO NACIONAL DE ESTADÍSTICA. Encuesta de Inserción Laboral de Titulados Universitarios 2014. Avance de Resultados. Available at: http://www.ine.es/prensa/np957.pdf. Accessed: 25 Sep. 2018.

IRIONDO, Iñaki. Evaluación del impacto de la movilidad Erasmus en los salarios y el empleo de los recién graduados. In: Cordero, José Manuel and Rosa Simancas, coords. XXV Jornadas de la Asociación de Economía de la Educación, 753-770, 2016.

JIMÉNEZ, Oscar. La traducción técnica inglés-español: didáctica y mundo profesional. Granada: Comares, 2002.

KELLY, Dorothy. A Handbook for Translator Trainers. Manchester: St Jerome Publishing. 2005 .

KUZNIK, Anna. El contenido de los puestos de trabajo de los traductores. El caso de los traductores internos en las empresas de traducción de Barcelona. Doctoral thesis, Universitat Autònoma de Barcelona, 2010.

Puestos de trabajo híbridos. Cuatro indicadores del carácter heterogéneo de los puestos de trabajo internos en traducción. Sendebar, 22: 283-307, 2011.

Translation as a Paradigmatic Universal, Post-Industrial, Knowledge-Based and Innovative Service. inTRAlinea. online translation journal. Special Issue, edited by Maria Piotrowska \& Sergiy Tyupa, Challenges in Translation Pedagogy, 2014.

. Work content of in-house translators in small and medium-sized industrial enterprises. Observing real work situations. JoSTrans. The Journal of Specialised Translation, 25: 213-231, 2016.

LEE, Donna; Foster, Emma and Snaith, Holly. Implementing the Employability Agenda: A Critical Review of Curriculum Developments in Political Science and International Relations in English Universities. Politics, 36(1), 95-111, 2016. 
MEC. Real Decreto 55/2005, de 21 de enero, por el que se establece la estructura de las enseñanzas universitarias y se regulan los estudios universitarios oficiales de Grado. Publicado en el BOE $n^{\circ} 21$ de 25 de enero de 2005.

Ministerio de Cultura, Libro blanco de la traducción editorial en España. Madrid: Ministerio de Cultura, 2010.

MONZÓ, Esther. La professió del traductor juridic $i$ jurat: descripció sociològica del profesional i anàlisi discursiva del transgènere. Doctoral thesis, Universitat Jaime I, 2002.

MOREAU, Marie-Pierre; LEATHHWOOD, Carole. Graduates' employment and the discourse of employability: a critical analysis. Journal of Education and Work, 19(4):305$324,2006$.

OCDE. Estadísticas. Available at: http://www.oecd.org/centrodemexico/estadisticas/. 2016. Accessed: 30 Nov, 2017.

ORTH, Dorothy. Presentación del estudio de mercado de la traducción en España. Primeras Jornadas de Traducción e Interpretación Expolingua. Madrid: ACT (Agrupación de Centros Especializados de Traducción). 2005

PACTE (alphabetical order): Hurtado Albir, A. (principal researcher). Galán-Mañas, A., Kuznik, A., Olalla-Soler, C., Rodríguez-Inés, P., Romero, L. Competence levels in translation: working towards a European framework. The Translator and Interpreter Trainer (ITT), 12(2), 111-131, 2018.

PLANAS, J. La relación entre educación y empleo en Europa. Papers, 94(4), 1047-1073, 2011.

RODRIGUES, Margarida. Does Student Mobility during Higher Education Pay? Evidence from 16 European Countries. Luxemburg: European Commission, 2013.

RODRÍGUEZ DE CÉSPEDES, Begoña. Addressing employability and enterprise responsibilities in the translation curriculum. The Interpreter and Translator Trainer, 11(23):107-122, 2017.

ROISS, Silvia. El mercado de la traducción inversa en España. Un estudio estadístico. Hermêneus. Revista de Traducción e Interpretación, 3:397-408, 2001.

TEICHLER, Ulrich. Student mobility in Europe: The informational value of official statistics and graduate surveys. In: Adrian Curaj, Peter Scott, Lazar Vlasceanu and Lesley Wilson, eds. European higher education at the cross roads: Between the Bologna Process and national reforms. Dordrecht: Springer, 485-509, 2012. 
. Graduados y empleo: investigación, metodología y resultados. Buenos Aires: Miño y Dávila editores, 2005.

\section{Appendices}

\section{Appendix 1. Summary of data and variables included in this study}

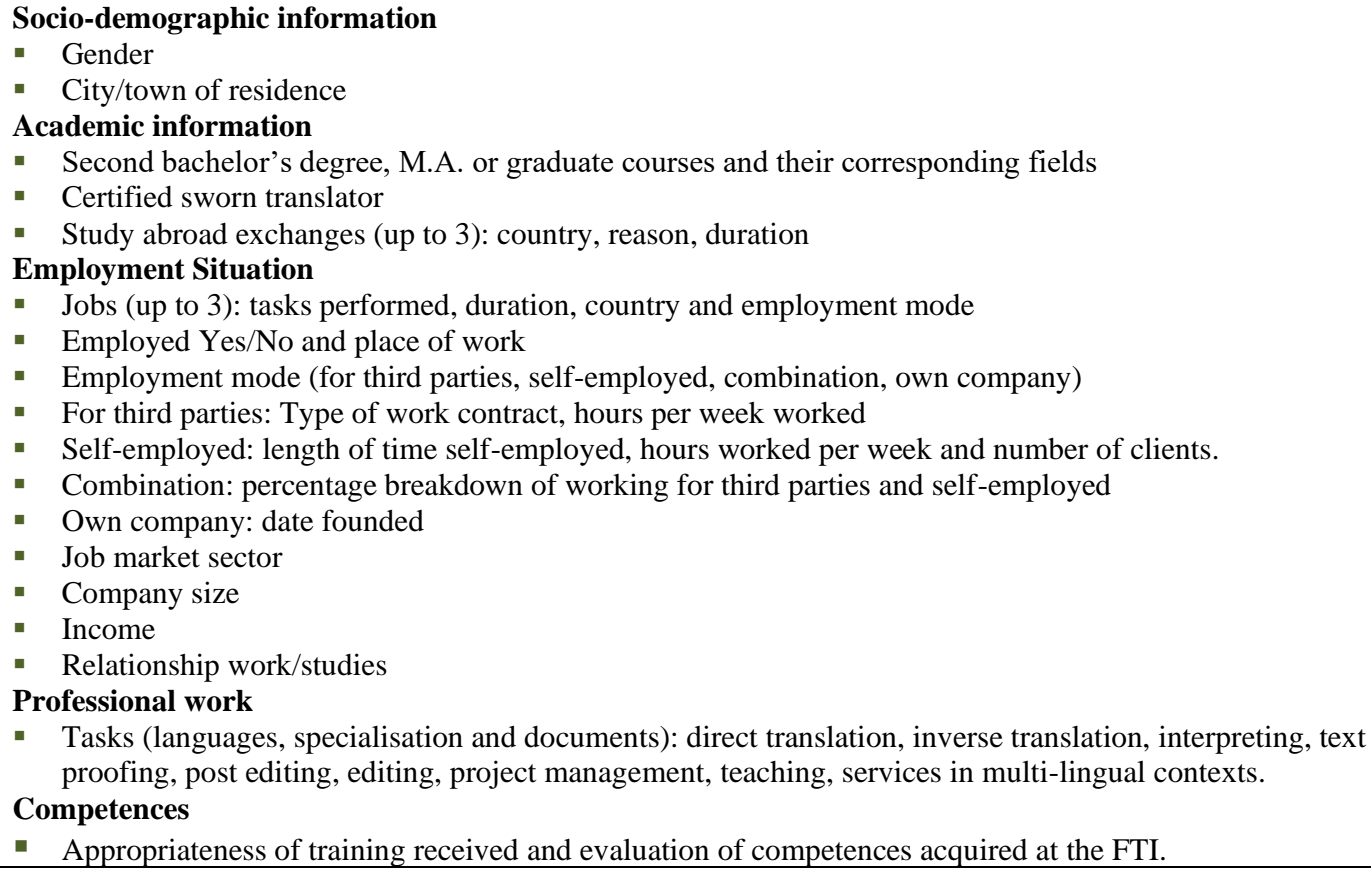

